Article

\title{
Sustainable Ventilation Strategies for a Medium-Sized Space with Regional Effect
}

\author{
Ming-Lun Alan Fong
}

check for

updates

Citation: Fong, M.-L.A. Sustainable Ventilation Strategies for a

Medium-Sized Space with Regional Effect. Sustainability 2021, 13, 4651.

https://doi.org/10.3390/su13094651

Academic Editor: Alberto Giretti

Received: 6 December 2020

Accepted: 2 April 2021

Published: 22 April 2021

Publisher's Note: MDPI stays neutral with regard to jurisdictional claims in published maps and institutional affiliations.

Copyright: (C) 2021 by the author. Licensee MDPI, Basel, Switzerland. This article is an open access article distributed under the terms and conditions of the Creative Commons Attribution (CC BY) license (https:// creativecommons.org/licenses/by/ $4.0 /)$.
Division of Building Science and Technology, College of Engineering, City University of Hong Kong, Hong Kong, China; alanfong@cityu.edu.hk; Tel.: +852-3442-6475

\begin{abstract}
The analysis of ventilation strategies is fundamentally affected by regional climate conditions and local cost databases, in terms of energy consumption, $\mathrm{CO}_{2}$ emission and cost-effective analysis. A systematic approach is covered in this paper to estimate a local economic and environmental impact on a medium-sized space located in two regions during supply-and-installation and operation phases. Three ventilation strategies, including mixing ventilation (MV), displacement ventilation (DV) and stratum ventilation (SV) were applied to medium-sized air-conditioned space with this approach. The trend of the results for three ventilation systems in the life cycle assessment (LCA) and life cycle cost (LCC) analysis is $\mathrm{SV}<\mathrm{DV}<\mathrm{MV}$. The result of $\mathrm{CO}_{2}$ emission and regional LCC shows that SV is the lowest one in both regional studies. In comparison with the Hong Kong Special Administrative Region (HKSAR) during 20 Service years, the case analysis demonstrates that the percentage differences in LCC analysis of MV, DV \& SV in Guangdong are less than 20.5\%, $19.4 \%$ and $18.82 \%$ respectively. Their $\mathrm{CO}_{2}$ emission of MV, DV and SV in Guangdong are more than HKSAR in $10.69 \%, 11.22 \%$ and $12.05 \%$, respectively. The present study could provide information about regional effects in the LCA and LCC analysis of three ventilation strategies emissions, and thereby help set up models for decision-making on high efficiency and cost-effective ventilation strategy plans.
\end{abstract}

Keywords: LCA; LCC; mixing; displacement; stratum ventilation strategies; regional effect

\section{Regional Analysis for MV, DV, and SV}

A building's lack of high efficiency and cost-effective ventilation system has proved to be one of the main sources of increasing energy consumption and carbon emissions [1,2]. Hence, given concerns about the consequences of global warming, energy conservation and emission reduction is a hot topic in the research relevant to building ventilation systems. Global climate change due to human activity becomes an exhilarating emergency and a grave problem.

Several developed countries have a long-term national greenhouse gas emission reduction program [3]. In China, the Fourteenth Five-Year Plan for national economic and social development focuses on improving building energy efficiency standards, proactively controlling carbon emissions, and strengthening energy consumption management in high energy consumption industries to achieve peak carbon emissions targets as soon as possible [4-6]. China pledged to reduce carbon intensity by 60-65\% compared with its 2005 level [7], as well as to increase non-fossil energy to approximately $20 \%$ of primary energy consumption [8] and to achieve peak carbon emissions reduction in 2030 [9]. The current energy policy for Hong Kong's Built Environment 2015-2025+ [10] is implementing for Hong Kong's buildings to reduce the peaking of greenhouse gas emission by an earlier date.

In general, a heating ventilation and air conditioning (HVAC) system is identified as the major operational energy consumer in buildings [11]. According to "Hong Kong Energy End-use Data 2020", 67\% of the total electricity in Hong Kong is consumed by the commercial sector. For instance, $30 \%$ of the total electrical energy, used by the HKSAR commercial sector is consumed by installations of room air conditioning [12]. 
Life cycle assessment (LCA) is a widely accepted approach for evaluating the overall emissions from various processes in the whole service life of buildings [13]. Additionally, regional life cycle assessment (regional LCA) is a useful instrument for forecasting the rapid increase in $\mathrm{CO}_{2}$ emission. This assessment instrument is used globally by industry and governmental authorities as a method for managing the environment [14]. The environmental impact of buildings can also be determined by other environmental assessment strategies and tools that are currently being used [15], including the Leadership in Energy and Environmental Design (LEED) model from the United States of America [16], the Building Research Establishment Environmental Assessment Method (BREEAM) from the United Kingdom [17], Green Star from the Commonwealth of Australia [18], the Hong Kong Special Administrative Region (HKSAR) tool [19], and Green Mark method from the Republic of Singapore [20]. The powerful contribution provided by these tools is that they help us to analyze the performance of buildings [21-23]. However, the embedded energy consumed and the regional effect of air-conditioning systems cannot be directly quantified in all phases of analysis. The invention of a life cycle approach counts every important source of energy coming into a building and every $\mathrm{CO}_{2}$ emission coming out of the building, with the entire process considering a building's specific region and the components of diverse cross-regional ventilation systems. The values of the individual components of the various inventories are regionally derived from a general inventory database. Depending on the region and country, each component in a life cycle inventory has a defined system price boundary. These include the Cycle Cost (LCC) Tool developed for HKSAR commercial buildings [19,24-26], Ecoinvent [27], European reference Life Cycle Database (ELCD) [28], and eBalance [29].

In the planning phase, the embodied energy in both the supply-and-installation phase and the day-to-day operational energy required by alternative ventilation strategies should be considered by the person in charge, to lower the amount of $\mathrm{CO}_{2}$ emission in various regions. The total accumulated energy of a building's ventilation system should not only consider the expended operational energy consumption in maintaining indoor environmental quality by the processes such as ventilation in an HVAC system but should also take into consideration all embedded energy hidden in the processes of production of building materials, transportation, cast in situ construction, and final demolition and disposal. To produce useful knowledge about the amount of carbon emission in operating a building, several investigators discussed the energy consumed during various phases of the life cycle of a building and found that each phase has various effects [23,30-36]. Concerning the life cycle stage, carbon emissions are often presented in the following phases: planning, design, construction, installation, testing and commissioning (T\&C), operation, and finally, disposal [37-39]. The various phases are categorized by the United States Environmental Protection Agency (US EPA) [40].

There are two distinct phases presented in this paper: (a) Supply-and-installation phase, which considers the products used in the construction process; and (b) Operation phase, which compares the service and maintenance of three ventilation strategies. Reducing the number of carbon emissions during the supply-and-installation phase is of paramount importance as a result of regional LCA, and it influences consideration of the degree to which the three various ventilation strategies in the various regions provide equal thermal comfort and efficiency [36]. The most important aspects of the building design are to lower the operational energy demand and to show high-performance energy efficiency throughout the life cycle in various region's buildings.

The optimized design of a ventilation strategy not only increases the opportunity for reducing the $\mathrm{CO}_{2}$ emission over the service life of a building system but also provides a comfortable environment during the operational period regardless of region. For instance, reducing the power consumed by the centralized HVAC system by increasing the indoor enthalpy set point and can reduce carbon emissions and also achieve a better indoor air quality in breathing zones [41-43], while using optimized weather data and consider building system size can minimize a building's lifecycle cost [44]. Furthermore, during 
the planning and design phase, the choice of apparatus, materials, and technology for different air distribution provides a chance to cut down the carbon emissions $[45,46]$ in various regions.

In a review of the practical update of LCA normalisation for all LCA impact categories. Context of environmental life cycle assessment (LCA), life cycle impact assessment (LCIA) is one of the central issues concerning modelling and methodological data collection. Normalisation factors are used to weighting the important aspects to enhance the reliability and accuracy of LCIA. In GLOBOX model is only focuses on the assessment of toxicityrelated impacts, and the collection of normalisation data for chemicals matter [47]. The integrated model integrates a crop model, DNDC (DeNitrification-DeComposition), with life cycle assessment (LCA) and economic analysis models using a GIS-based integrated platform, ENVISION enables LCA practitioners to conduct integrated economic analysis and LCA on a regional scale while capturing the variability of soil emissions due to variation in regional factors during the production of crops and biofuel feedstocks [48]. The author cannot find out any article for studying various ventilation strategies with regional effect. This paper could be regarded as an effort contributing to narrowing the gap on this regional effect of a ventilation strategy study.

\section{Research Methodology}

A quantitative method adopted to study the effect on the environment of components of building ventilation system and their equipment, as well as demand to utilize the regional LCC \& LCA. The financial and environmental analysis was based on equal conditions of thermal comfort for different ventilation strategy in HKSAR and Guangdong. The case study focused on estimating economic benefits differences by introducing alternative ventilation strategies in HKSAR and Guangdong. MV, DV and SV were involved in the normal air-conditioned three-row medium-sized space seating pattern with sizes of $6100 \mathrm{~mm}$ (width) $\times 8800 \mathrm{~mm}$ (length) $\times 2400 \mathrm{~mm}$ (height) in the supply-and-installation and operation phase (See Figure 1).

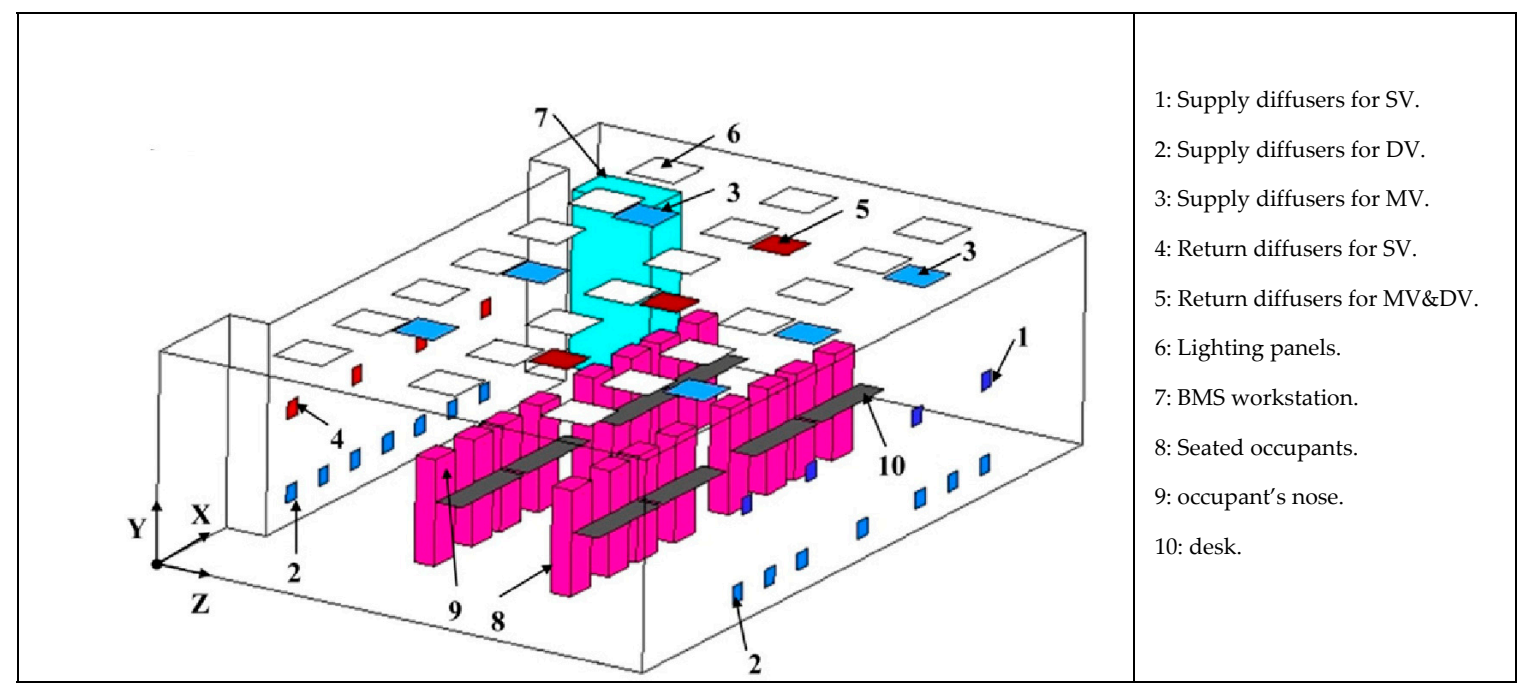

Figure 1. Mixing-, displacement-, stratum-ventilated medium-sized space.

Three ventilation strategies were applied in the local industry practices data in HKSAR and Guangdong to measure their cost investment, consumption of energy and $\mathrm{CO}_{2}$ emission. TRNSYS software [49]. used to simulate year-round energy spend for the three ventilation systems. Industrial data explanation, with the extent of energy-saving, restricted to life-saving of electricity for the support of the design of various ventilation strategies. 


\subsection{Regional LCA Boundary for Comparison}

This study involved the processes from procurement of raw materials to system manufacturing, in situ construction and the discarding phases at the termination of the service life of the system. The recycling process is excluded in this study due to different waste management policy in HKSAR and Guangdong. The life-cycle inventory was compiled using the regional LCA method. The raw fabrication material for different ventilation system components was mostly mined in Mainland China. MV formed as a basis to compare the SV and DV during supply-and-installation and operation phases in a full-scale model with particular comfort condition in HKSAR and Guangdong.

The data on embedded energy and carbon emissions of each material in the Hong Kong case was taken out primarily from the website of the HKSAR Government Department of Electrical and Mechanical Services (EMSD) [24] and another directory in Mainland China [29]. The primary cost of each construction component was contributed by the local contractors and industry database [50,51]. The main component and sub-component of the ventilation systems were made in China. Therefore, raw materials were transported within China and from all over the world to the by- or main-product manufacturing factories in different cities of China. All the ventilation system components were produced and assembled in the designated city of Chinese Mainland and shipped from the main factory in Dongguan to the HKSAR's and Guangdong's site for installation. The ventilation systems installation was completed in the classroom in Hong Kong. In the supply-and-installation process, every part of the systems including the electrical cabling and water piping installation were being considered. Due to the different waste management policies between HKSAR and Guangdong, the disposal of the ventilation installation in this regional LCA was excluded. For instance, the landfills of HKSAR are being filled up with solid waste disposal at a dangerous rate. The goal is to lower the municipal solid waste per capita disposal rate by $40 \%$ by 2022 as a reference to 2011 [52]. Unless granted by the Environmental Department of HKSAR, all the demolition material from construction is not allowed to dispose of the landfills in Hong Kong [53]. If such a process is considered, the summation of total inventories must include the energy demand and the production of greenhouse gas for reuse, recycling, landfill, and incineration. Due to unfair information on the treatment for disposal and their data of inventories in different regions, thus, that energy demand and carbon emissions did not to be included. LCI analysis method often used in Life cycle impact assessment without adding any weighting factors as well as an impact indicator of the energy used in the life cycle which embedded, and usage of operational energy were included.

\subsection{Supply-and-Installation, Operation Phases in Various Regions}

The same capacity AHU used in HKSAR's ad Guangdong's cases. The physical weight, embedded energy, and embedded carbon of the AHU in the supply-and-installation phase were estimated as $222.34 \mathrm{~kg}, 14482.46 \mathrm{MJ}$ and $1100.71 \mathrm{~kg} \mathrm{CO}_{2}$-eq respectively [26]. The data of embedded energy and embedded carbon are extracted from eBalance [29] as well as Life Cycle Inventory (LCI) data which is developed by EMSD [19,24].

eBalance is a regional LCA software that contains the Chinese Life Cycle Database (CLCD). The software is developed by Sichuan University and IKE Environmental Technology Co. Ltd. in China. The data gathered in the database are representing the technology of production and the average level of the market in China. It provides the data support for LCA analysis and energy-saving forecast evaluation for the locally made products. Also, it encompasses the Ecoinvent database as well as the European Reference Life Cycle Database (ELCD) in the Life Cycle Inventory database of eBalance. Due to the limited access to CLCD from the free version eBalance, some of the embedded energy data are referred to as the Ecoinvent and ELCD database stored in the eBalance. The Ecoinvent and ELCD can provide the data of products, which the inventory of products are being imported into Mainland China, as well as any inventory is not yet available in CLCD's database. 
The EMSD of HKSAR develops its LCI data by employing the life cycle assessment technique. The data can be used to evaluate the direct and indirect import of the material manufacturing process. The LCI developed by EMSD is based on the regional LCA and regional LCC data. The data are conducted by the materials and components adopted in 28 commercial buildings in Hong Kong using research software life cycle energy analysis (LCEA). The dictated components and materials, which has the largest environmental impacts on the buildings, can be distinguished by the LCEA [19]. Other well-recognized building life-cycle evaluation software includes: Life Cycle Assessment Data and Software developed by Athena Institute [54], Building for Environmental and Economic Sustainability software developed by National Institute of Standards and Technology (NIST) [55], ENVEST 2 developed by BRE [56], etc. Section 3.1.2 tabulated the cumulative embedded energy of various components installed for MV, DV, and SV to be adopted in HKSAR's and Guangdong's cases.

The energy consumption in the operating phase for MV, DV and SV in the various region were evaluated in the thermal comfort model at their thermal neutral temperature [57]. Such neutral temperature was determined by a large number of individuals voting on an ASHRAE 7-point thermal sensation scale based on the heat balance of the human body. The thermal sensation vote is scaled from Cold (-3), Cool (-2), Slightly Cool $(-1)$, Neutral (0), Slightly Warm (+1), Warm (+2), and Hot (+3) [58-60]. The influencing factors of such temperature not only includes Metabolic rate of the human body, Clothing Insulation, Air Temperature, Mean Radiant Temperature, Airspeed, Relative Humidity, Natural Ventilation as well as another potential environmental criterion [60], but also every system of air distribution is adopted [36,57]. The neutral temperatures are $2.7^{\circ} \mathrm{C}$ and $2.2^{\circ} \mathrm{C}$ higher than the conventional MV and DC representatively by adopting the SV at a 10 Air Change per Hour of supply airflow rate [36,57]. In the earlier finding by other investigators, the respective natural temperatures of $24.6^{\circ} \mathrm{C}$ for $\mathrm{MV}, 25.1^{\circ} \mathrm{C}$ for $\mathrm{DC}$ and $27.3^{\circ} \mathrm{C}$ for $\mathrm{SV}$ are matching this study [57].

An energy simulation software TRNSYS was adopted in this study to simulate the all-year-round energy consumption for MV, DV, and SV at their natural temperatures. The simulations of a centralized air-conditioning system not only included primary circuits which consist of chillers, pumps \& etc., but also the secondary circuits which consist of terminal units, pumps \& etc. [38]. The simulations were rendered for 365 days based on Hong Kong's typical meteorological year (TMY) weather data and employed a 3-min simulation time interval [61]. Territory-Wide $\mathrm{CO}_{2}$ emission factors adopted in the simulation are $0.54 \mathrm{~kg} \mathrm{CO}_{2}-\mathrm{eq} / \mathrm{kWh}$ and $0.63 \mathrm{~kg} \mathrm{CO}$-eq/ $\mathrm{kWh}$ for Hong Kong and Guangdong respectively. These data were used to estimate the equivalent amount of $\mathrm{CO}_{2}$ emission from the figures of estimated energy consumption, in term of KWh. The simulation of primary energy consumption and system performance was conducted in various situations with part-load conditions. The results of different conditions were compared.

The study's regional LCA analysis used their local contracting cost of three ventilation strategies (MV, DV, SV) in the supply-to-installation phase, as well as the $\mathrm{CO}_{2}$ emission evaluated from the operating energy consumption results. Different time viewpoints were used to make a comprehensive evaluation. The periods selected with a 5-year interval, which are $5,10,15$, and 20 years.

\section{Regional Analysis for MV, DV, and SV}

This case study on the $\mathrm{CO}_{2}$ emission of three ventilation systems, including $\mathrm{MV}, \mathrm{DV}$, and SV was separated into the process of the supply-and-installation phase as well as the operation phase. The $\mathrm{CO}_{2}$ emission during the supply-and-installation phase composed of emission from the materials used in the ventilation installation. The medium-sized classroom adopted in this study is within an air-conditioned zone located in the interior zone of the building. Therefore, the energy used is primarily to handle the internal load as well as ventilation load only. 


\subsection{Supply-and-Installation Phase \\ 3.1.1. Initial Cost}

Appropriate cost data shall be acquired first for the assessment of three specific ventilation systems. Initial costs of MV, DV \& SV are shown in Table 1.

Table 1. The initial cost for three ventilation systems in HKSAR \& Guangdong.

\begin{tabular}{|c|c|c|c|c|c|}
\hline Item & General Description of Each Construction Materials & $\begin{array}{l}\text { HKSAR } \\
\text { HK\$/Unit }\end{array}$ & HK\$ & $\begin{array}{l}\text { Guangdong } \\
\text { RMB } \$ / \text { Unit }\end{array}$ & RMB\$ \\
\hline 1.1 & $\begin{array}{c}1 \times \text { air handling unit completed } \\
1 \times 450 \mathrm{~L} / \mathrm{s} \text { supply air fan }\end{array}$ & 50,000 & 50,000 & 11,118 & 11,118 \\
\hline 1.2 & 1 set of framework support for ceiling mounted AHU & 6000 & 6000 & 5000 & 5000 \\
\hline 1.3 & $2 \times$ duct silencers & 4000 & 8000 & 2000 & 4000 \\
\hline 1.4 & 26 m chilled water pipework & 450 & 11,700 & 286 & 8580 \\
\hline 1.5 & $20 \mathrm{~m}$ condensate drain pipework & 320 & 6400 & 161 & 3220 \\
\hline 1.6 & 1 set of electrical power control & 50,000 & 50,000 & 40,000 & 40,000 \\
\hline 1.7 & $\begin{array}{l}1 \text { set of Direct Digital Controller (DDC) control equipment } \\
\text { completed with necessarily valves and sensors. }\end{array}$ & 70,000 & 70,000 & 43,637 & 43,637 \\
\hline $2.1_{\mathrm{MV}}$ & $45 \mathrm{~m}^{2}$ air ductworks with accessories (for MV) & 300 & 13,500 & 131 & 5895 \\
\hline $2.2 \mathrm{MV}$ & $45 \mathrm{~m}^{2}$ thermal insulation for air ductwork (for MV) & 180 & 8100 & 240 & 10,800 \\
\hline $2.3_{\mathrm{MV}}$ & $6 \times$ Supply Air Grille $($ For MV) & 460 & 2760 & 350 & 2100 \\
\hline $2.4_{\mathrm{MV}}$ & $3 \times$ Return Air Louver (For MV) & 507 & 1520 & 350 & 1050 \\
\hline $3.1_{\mathrm{DV}}$ & $29 \mathrm{~m}^{2}$ air ductworks with accessories (for DV) & 300 & 8700 & 131 & 3930 \\
\hline $3.2 \mathrm{DV}$ & $29 \mathrm{~m}^{2}$ thermal insulation for air ductwork (for DV) & 200 & 5800 & 240 & 7200 \\
\hline $3.3_{\mathrm{DV}}$ & $8 \times$ Supply Air Grille (for DV) & 230 & 1840 & 350 & 2800 \\
\hline $3.4_{\mathrm{DV}}$ & $3 \times$ Return Air Louver (for DV) & 310 & 930 & 350 & 1050 \\
\hline $4.1_{\mathrm{SV}}$ & $43 \mathrm{~m}^{2}$ air ductworks with accessories (for SV) & 300 & 12,900 & 131 & 5633 \\
\hline $4.2 \mathrm{SV}$ & $43 \mathrm{~m}^{2}$ thermal insulation for air ductwork (for SV) & 200 & 8600 & 232 & 9976 \\
\hline $4.3_{\mathrm{SV}}$ & $4 \times$ Supply Air Grille (for SV) & 277 & 1110 & 250 & 1000 \\
\hline \multirow[t]{3}{*}{$4.4 \mathrm{SV}$} & $4 \times$ Return Air Louver (for SV) & 350 & 1400 & 250 & 1000 \\
\hline & \multicolumn{5}{|c|}{ Initial Cost, IC (HK\$) for three ventilation systems } \\
\hline & & \multicolumn{2}{|c|}{ HKSAR } & \multicolumn{2}{|c|}{ Guangdong *1 } \\
\hline $\mathrm{IC}_{\mathrm{MV}}$ & $\begin{array}{c}\text { Items of } 1.1+1.2+1.3+1.4+1.5+1.6+1.7+2.1_{\mathrm{MV}}+ \\
2.2_{\mathrm{MV}}+2.3_{\mathrm{MV}}+2.4_{\mathrm{MV}}:=\end{array}$ & \multicolumn{2}{|c|}{$\begin{array}{l}\mathrm{HK} \$ 227,980 \\
\quad(\text { Base }) * 2\end{array}$} & \multicolumn{2}{|c|}{$\begin{array}{c}\text { RMB } ¥ 135,400 \\
\text { or } \mathrm{HK} \$ 162,480 \\
\left(\text { Base) }{ }^{* 2}[-28.73 \%] * 3\right.\end{array}$} \\
\hline $\mathrm{IC}_{\mathrm{DV}}$ & $\begin{aligned} \text { Items of } 1.1+1.2+ & 1.3+1.4+1.5+1.6+1.7+3.1_{\mathrm{DV}}+3.2_{\mathrm{DV}} \\
& +3.3_{\mathrm{DV}}+3.4_{\mathrm{DV}}=\end{aligned}$ & \multicolumn{2}{|c|}{$\begin{array}{l}\mathrm{HK} \$ 219,370 \\
(-3.78 \%) * 2\end{array}$} & \multicolumn{2}{|c|}{$\begin{array}{c}\text { RMB } ¥ 130,535 \\
\text { or HK } \$ 156,642 \\
(-3.59 \%) * 2[-28.59 \%] * 3\end{array}$} \\
\hline $\mathrm{IC}_{\mathrm{SV}}$ & 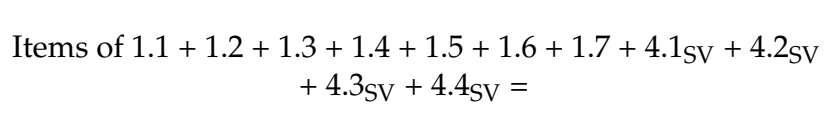 & \multicolumn{2}{|c|}{$\begin{array}{l}\mathrm{HK} \$ 226,110 \\
(-0.82 \%) * 2\end{array}$} & \multicolumn{2}{|c|}{$\begin{array}{c}\text { RMB } ¥ 133,164 \\
\text { or HK } \$ 159,797 \\
(-1.65 \%) * 2[-29.33 \%] * 3\end{array}$} \\
\hline
\end{tabular}

${ }^{* 1}$ Exchange rate from HK\$ to RMB $¥$ is 1.2 for the above regional cost analysis. ${ }^{* 2}$ Percentage difference of the initial cost of DV and SV comparison with MV in the same region. ${ }^{* 3}$ Percentage difference of the regional initial cost of correspondence ventilation installation.

In comparing the calculated initial cost (IC) for MV, DV and SV in HKSAR are tabulated in Table 1, the initial cost difference in Guangdong is less than HKSAR for MV, DV and SV are $28.73 \%, 28.59 \%$ and $29.33 \%$ respectively (hereafter with representing as $-28.73 \%$, $-28.59 \%$ and $-29.33 \%$ ). These costs are used for the studies in the following sections to integrate with regional embedded energy and carbon emission.

\subsubsection{Cumulative Embedded Energy of Each System}

The $\mathrm{CO}_{2}$ released in alternative ventilation strategies from the supply-and-installation phase had assessed by the identical model of air handling unit (AHU) with all necessary system accessories for bath regional study in HKSAR and Guangdong. To simplify the analysis of the material used in AHU, the same capacity model is adapted. From the other similar study, the SV's peak cooling load is approximately 70\% of the MV [62]. The peak cooling load simulations of various ventilation strategies were conducted by TRNSYS [49]. An identical AHU was introduced due to the unavailability of an exactly needed capacity 
AHU in the market. In compliance with the catalogue and installation manual of the manufacturer, the numbers of each assembly part are calculated by multiplying the embedded energy per unit mass $(\mathrm{MJ} / \mathrm{kg}$ ) and mass $(\mathrm{kg})$. The embedded energy of all components and connecting accessories can be estimated [26]. In this database, the embedded energy inventories are for the supply-and-install process. All the data of processes across the whole regional LCA boundary have been included. For a typical AHU, the total cumulative energy and carbon emissions are 14,482 $\mathrm{MJ}$ and $1100 \mathrm{~kg} \mathrm{CO}$-eq [26].

In Guangdong, a greater amount of electricity is produced by coal-burning, in comparison with Hong Kong. So, the $\mathrm{CO}_{2}$ emission factor in Guangdong is higher than in Hong Kong. However, due to the different outdoor conditions in Hong Kong and Guangdong, the electricity consumption in Guangdong is less than in Hong Kong. In light of this, the $\mathrm{CO}_{2}$ saving in the operation phase in Guangdong is higher than in Hong Kong.

Listed in Table 2 are the components of the three ventilation strategies. Those components are produced in the area of the Pearl River in Guangdong, People Republic of China. The embedded energy of the entire system with all installed accessories are 41,408 MJ for MV, 31,953 MJ for DV, and 36,346 for SV respectively. The $\mathrm{CO}_{2}$ emission of different ventilation systems are $3057 \mathrm{~kg} \mathrm{CO}_{2}$-eq for $\mathrm{MV}, 2364 \mathrm{~kg} \mathrm{CO}_{2}$-eq for DV and $2639 \mathrm{~kg} \mathrm{CO}_{2}$-eq for SV respectively.

Table 2. Cumulative embedded energy of various installed accessories (made in Dongguan) for three ventilation systems.

\begin{tabular}{|c|c|c|c|c|}
\hline \multicolumn{2}{|c|}{ General Description of Each Major Component in Various Systems } & Mass (kg) & $\begin{array}{l}\text { Embedded Energy (MJ) } \\
{[\text { Mass, } \mathrm{kg} \times \text { Energy }} \\
\left.\text { Intensity }{ }^{*}, \mathrm{MJ} / \mathrm{kg}\right]\end{array}$ & $\begin{array}{c}\text { Embedded Carbon } \\
\left(\mathrm{kg} \mathrm{CO} \mathrm{CO}_{2} \text {-eq) }\right.\end{array}$ \\
\hline \multirow{5}{*}{$\begin{array}{l}\text { (1.2) Accessories } \\
\text { of MV: }\end{array}$} & (1.1) Air Handling Unit: & 222 & 14,482 & 1100 \\
\hline & $45 \mathrm{~m}^{2} \times 2 \mathrm{~mm}$ galvanized iron air ductwork & 708 & 10,129 & 585 \\
\hline & $45 \mathrm{~m}^{2} \times 13 \mathrm{~mm}$ fiberglass insulation & 281 & 8901 & 694 \\
\hline & $45 \mathrm{~m}^{2} \times 0.1 \mathrm{~mm}$ aluminum foil insulation for ductwork & 12 & 2564 & 220 \\
\hline & $3.24 \mathrm{~m}^{2} \times 3 \mathrm{~mm}$ aluminum for supply \& return diffuser & 26 & 5332 & 458 \\
\hline \multirow{5}{*}{$\begin{array}{c}\text { (1.3) Accessories } \\
\text { of DV: }\end{array}$} & Cumulative energy of MV, (1.1) + (1.2): & 1249 & 41,408 (Base) & 3057 (base) \\
\hline & $30 \mathrm{~m}^{2} \times 2 \mathrm{~mm}$ galvanized iron air ductwork & 472 & 6752 & 390 \\
\hline & $30 \mathrm{~m}^{2} \times 13 \mathrm{~mm}$ fiberglass insulation & 187 & 5934 & 462 \\
\hline & $30 \mathrm{~m}^{2} \times 0.1 \mathrm{~mm}$ aluminum foil insulation for ductwork & 8 & 1709 & 147 \\
\hline & $1.80 \mathrm{~m}^{2} \times 3 \mathrm{~mm}$ aluminum for supply \& return diffuser & 15 & 3076 & 263 \\
\hline \multirow{6}{*}{$\begin{array}{c}\text { (1.4) Accessories } \\
\text { of SV: }\end{array}$} & Cumulative energy of DV, $(1.1)+(1.3)$ : & 904 & $31,953(-22.83 \%)$ & $2364(-22.68 \%)$ \\
\hline & $43 \mathrm{~m}^{2} \times 2 \mathrm{~mm}$ galvanized iron air ductwork & 679 & 9678 & 559 \\
\hline & $43 \mathrm{~m}^{2} \times 13 \mathrm{~mm}$ fiberglass insulation & 268 & 8505 & 663 \\
\hline & $43 \mathrm{~m}^{2} \times 0.1 \mathrm{~mm}$ aluminum foil insulation in ductwork & 12 & 2450 & 210 \\
\hline & $0.72 \mathrm{~m}^{2} \times 3 \mathrm{~mm}$ aluminum for supply \& return diffuser & 6 & 1231 & 107 \\
\hline & Cumulative energy of SV, (1.1) + (1.4): & 1187 & $36,346(-12.22 \%)$ & $2639(-13.69 \%)$ \\
\hline
\end{tabular}

*1 The energy intensities of galvanized iron, fibreglass, aluminium foil and aluminium are 14, 32, 214 and 205 MJ/kg respectively.

The travel distance of a vehicle from Dongguan to Guangdong and HKSAR is approximately $20 \mathrm{~km}$ and $150 \mathrm{~km}$ respectively. From the database of the Chinese Life Cycle contained in "eBalance" [29], Embedded energy is 2.474 MJ per ton-kilometre for an eightton lorry. For the three ventilation systems, the embodied energy in the transport of all components is described in Table 3.

Table 3. Regional LCA in HKSAR and Guangdong for their cumulative embedded energy in the transportation of the equipment/material/parts.

\begin{tabular}{|c|c|c|c|c|c|c|}
\hline \multirow{2}{*}{$\begin{array}{c}\text { Ventilation } \\
\text { System }\end{array}$} & \multirow{2}{*}{$\begin{array}{l}\text { Total Weight of Ventilation } \\
\text { System (kg or Ton) }\end{array}$} & \multirow{2}{*}{$\begin{array}{c}\text { Embedded Energy } \\
\text { Factor* }(\mathrm{MJ} / \text { Ton } \cdot \mathbf{k m})\end{array}$} & \multicolumn{2}{|c|}{ Distance $(\mathbf{k m})$} & \multicolumn{2}{|c|}{ Embedded Energy (MJ) } \\
\hline & & & HKSAR & Guangdong & HKSAR & Guangdong \\
\hline Mixing (MV) & 1249 or 1.249 & 2.474 & 150 & 20 & 464 & 62 \\
\hline Displacement (DV) & 904 or 0.904 & 2.474 & 150 & 20 & 336 & 45 \\
\hline Stratum (SV) & 1187 or 1.187 & 2.474 & 150 & 20 & 441 & 59 \\
\hline
\end{tabular}

* Embedded energy factor of $2.474 \mathrm{MJ} /$ Ton-km is used for transportation. 
The total carbon emissions during the supply-and-installation phase, including embedded energy of AHU and Transportation for the three ventilation strategies are summarized in Table 4. The annual $\mathrm{CO}_{2}$ emission of various ventilation systems in HKSAR are $6286 \mathrm{~kg}$ $\mathrm{CO}_{2}$-eq for MV, $4847 \mathrm{~kg} \mathrm{CO}_{2}$-eq for DV and $5522 \mathrm{~kg} \mathrm{CO}_{2}$-eq for SV respectively. In Guangdong, these are $7263 \mathrm{~kg} \mathrm{CO}_{2}$-eq for MV, $5604 \mathrm{~kg} \mathrm{CO}_{2}$-eq for DV and $6376 \mathrm{~kg} \mathrm{CO}_{2}$-eq for $\mathrm{SV}$ respectively. The percentage difference of annual $\mathrm{CO}_{2}$ emission between HKSAR and Guangdong for various systems is around $15 \%$.

Table 4. $\mathrm{CO}_{2}$ emission for MV, DV \& SV in supply-and-installation phase.

\begin{tabular}{|c|c|c|c|c|c|c|c|c|}
\hline \multirow{2}{*}{$\begin{array}{l}\text { Ventilation } \\
\text { System }\end{array}$} & \multicolumn{2}{|c|}{$\begin{array}{l}\text { Cumulative Embedded Energy } \\
\text { of AHU See Table } 2 \\
\text { + Transportation See Table } 3 \text {, MJ }\end{array}$} & \multicolumn{2}{|c|}{$\begin{array}{l}\text { Total Embedded } \\
\text { Energy }{ }^{\# 1}, \mathrm{MJ}\end{array}$} & \multicolumn{2}{|c|}{$\begin{array}{c}\text { Total Cumulative } \\
\text { Embedded Energy, kWh }{ }^{\# 2}\end{array}$} & \multicolumn{2}{|c|}{$\begin{array}{c}\text { Annual } \mathrm{CO}_{2} \text { Emission, } \\
\mathrm{kg} \mathrm{CO}_{2}-\mathrm{eq}^{\# 3}\end{array}$} \\
\hline & HKSAR & Guangdong & HKSA-R & Guangdong & HKSAR & Guangdong & $\begin{array}{l}\text { HKSAR } \\
\text { (base) }\end{array}$ & $\begin{array}{l}\text { Guangdong } \\
\text { (\% diff.) }\end{array}$ \\
\hline MV & $41,408+464$ & $41,408+62$ & 41,872 & 41,470 & 11,640 & 11,529 & 6286 & $7263(+15.55 \%)$ \\
\hline DV & $31,953+336$ & $31,953+45$ & 32,289 & 31,998 & 8976 & 8895 & 4847 & $5604(+15.62 \%)$ \\
\hline SV & $36,346+441$ & $36,346+59$ & 36,787 & 36,405 & 10,227 & 10,121 & 5522 & $6376(+15.46 \%)$ \\
\hline
\end{tabular}

\#1 Total embedded energy involved embedded energy in AHU and transportation. ${ }^{\# 2}$ Conversation factor of embedded energy from MJ to $\mathrm{kWh}$ is $0.278 .{ }^{\# 3}$ Conversation factor from $\mathrm{kWh}$ to $\mathrm{CO}_{2}$ assumes $0.54 \times \mathrm{kWh}$ for HKSAR, $0.63 \times \mathrm{kWh}$ for Guangdong.

\subsection{Operation Phase}

Energy Consumption of each system with regional effect

The regional LCA study is performed based on their estimated thermal neutral temperature of the different ventilation strategies. Under the condition of 10 Air Change per Hour (ACH), the neutral temperatures of Chinese youngster are found to be $24.6^{\circ} \mathrm{C}$ under mixing ventilation; $25.1{ }^{\circ} \mathrm{C}$ for under displacement ventilation; and $27.3^{\circ} \mathrm{C}$ under stratum ventilation through regression analysis $[25,26,57]$. The energy consumption during the operation phase was analyzed with identical baseline case together with alternatives, where different ventilation strategies are incorporated under their respective neutral temperatures. Total internal load of $2686 \mathrm{~W}$ are used in this operational analysis for three ventilation systems, including internal heats sources generated by a projector $(220 \mathrm{~W})$, a group of lamps $(1176 \mathrm{~W})$, a teaching computer set $(100 \mathrm{~W})$ and a portable electronic device per each student $(24 \times 80 \mathrm{~W})$, as well as the ventilation load of $10 \mathrm{~L} / \mathrm{s} /$ person for 25 people $(1190 \mathrm{~W})$. A central air-conditioning system in the energy analysis, including an air-cooled chiller, circulation pump, a ceiling-mounted AHU, the fan provides an energy simulation base. All components of the central air-conditioning system for this energy consumption in the TRNSYS simulation program are shown in Figure 2. Their weather data of HKSAR and Guangdong are tabulated in Table 5.

Table 5. The design weather condition of HKSAR and Guangdong.

\begin{tabular}{ccc}
\hline Outdoor Temperature, Celsius & HKSAR & Guangdong \\
\hline Summer Design, Dry Bulb & 35 & 35.1 \\
Summer Coincident, Wet Bulb & 29 & 26.3 \\
Summer Daily Range & 4.5 & 6.9 \\
Winter Design, Dry Bulb & 7 & 5.8 \\
Winter Coincident, Wet Bulb & 4.6 & 2 \\
\hline
\end{tabular}

The difference in energy consumption between Hong Kong and Guangdong would be explained in terms of outdoor temperature difference. Based on Table 5, the outdoor enthalpy in Hong Kong is slightly higher than in Guangdong. In light of this, it is expected that under the same indoor design condition, the energy consumed by the AHU in Hong Kong would be higher than in Guangdong.

All-year-round total energy consumptions of MV, DV and SV in HKSAR simulated by the TRNSYS program are 21,529 kWh, 16,495 kWh and 13,228 kWh respectively. In 
Guangdong, these are 20,402 kWh, 15,707 kWh and 12,690 kWh respectively. The energy consumption in Guangdong is slightly lower than in Hong Kong. The percentage difference of the energy data between HKSAR and Guangdong for various systems is around 4.1 to $5.2 \%$. The breakdown of each item is tabulated in Table 6 .

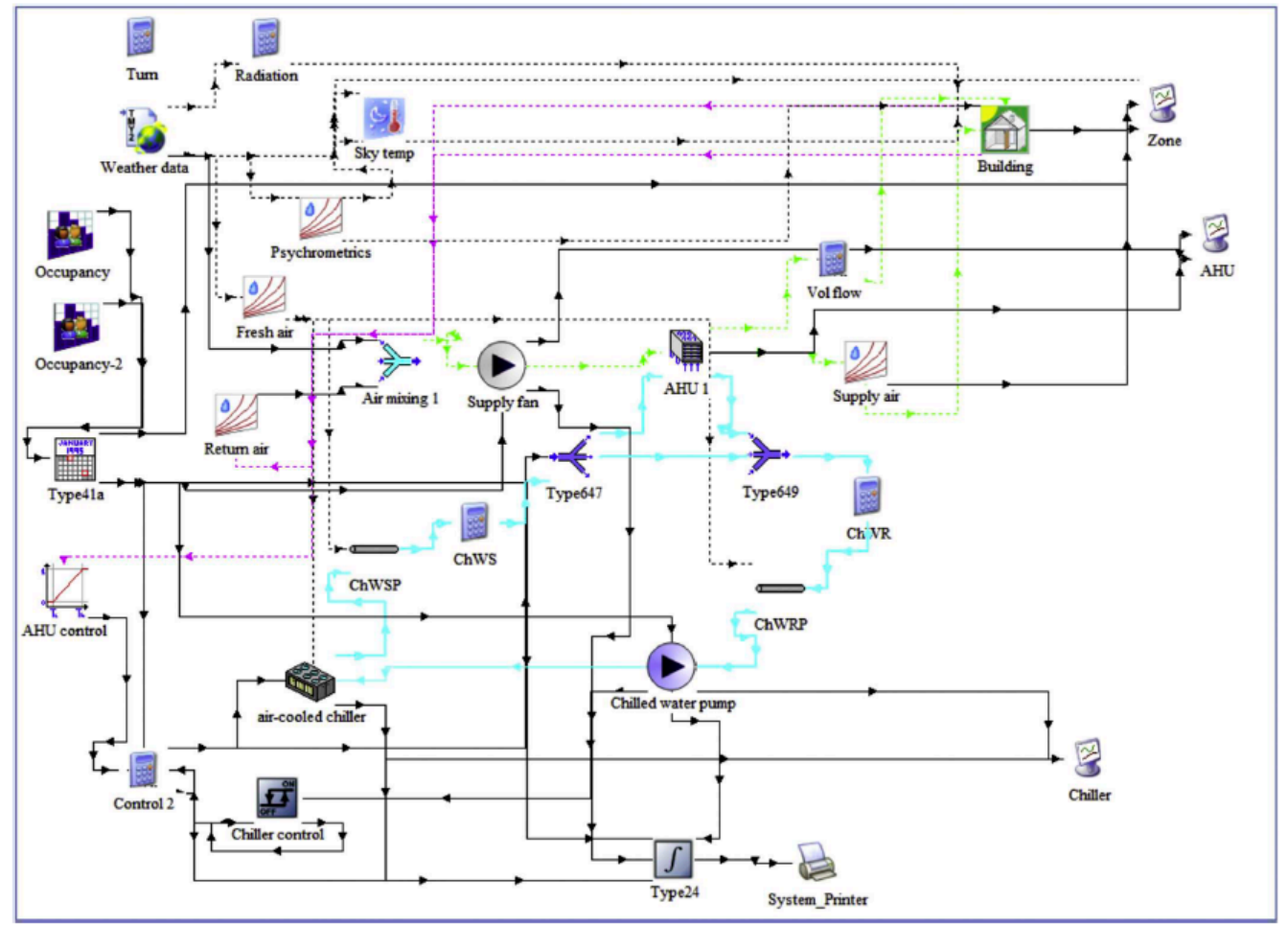

Figure 2. Component of the central air conditioning in TRNSYS simulation program.

\subsection{Regional LCA of Three Ventilation Systems for 20 Years}

Resultantly, the energy consumed during the operating phase for MV, DV, and SV in HKSAR \& Guangdong can be determined by multiplying the overall year-round energy consumption in term of $\mathrm{kWh}$, operation years in term of an hour, and $\mathrm{CO}_{2}$ emission factor in term of $\mathrm{kg} \mathrm{CO}_{2}$-eq $/ \mathrm{kWh}$. Table 7 provides the study of $\mathrm{CO}_{2}$ emission under (a) Supplyand-installation phase together with (b) Operation phase of MV, DV, and SV, along with the energy intake by the three ventilation strategies annually and their respective neutral temperature throughout the regional LCA for a 5-year interval. In the 20 years of operation, the trend of $\mathrm{CO}_{2}$ emission of the three ventilation strategies is $\mathrm{SV}<\mathrm{DV}<\mathrm{MV}$. The carbon emission of 238,806 $\mathrm{kg} \mathrm{CO}_{2}$-eq \& 264,323 $\mathrm{kg} \mathrm{CO}_{2}$-eq for MV, 182,987 \& 203,524 $\mathrm{kg} \mathrm{CO}_{2}$-eq for DV and 148,382 \& 166,256 $\mathrm{kg} \mathrm{CO}_{2}$-eq for SV are estimated in HKSAR \& Guangdong. The percentage difference of $\mathrm{CO}_{2}$ emission in Guangdong, based on HKSAR for MV, DV and SV is significantly varied, those are $10.69 \%, 11.22 \%$ and $12.05 \%$ respectively. 
Table 6. All-year-round energy consumption simulated for three ventilation systems in HKSAR and Guangdong.

\begin{tabular}{|c|c|c|c|c|c|c|c|c|c|c|c|}
\hline \multirow{2}{*}{$\begin{array}{l}\text { Ventilation } \\
\text { System }\end{array}$} & \multirow{2}{*}{$\begin{array}{c}\text { Room } \\
\text { Temp. }{ }^{* 1}\left({ }^{\circ} \mathrm{C}\right)\end{array}$} & \multirow{2}{*}{$\begin{array}{l}\text { Supply Air } \\
\text { Temp. }\left({ }^{\circ} \mathrm{C}\right)\end{array}$} & \multicolumn{2}{|c|}{ Chiller Water Temp. } & \multicolumn{2}{|c|}{ Chiller (kWh) } & \multicolumn{2}{|c|}{ Fan \& Pump (kWh) } & \multicolumn{2}{|c|}{ Total Power ${ }^{* 2}(\mathrm{kWh})$} & \multirow{2}{*}{$\frac{\% \text { diff. }}{\{[b]-[a] /[a]}$} \\
\hline & & & Low. $\left({ }^{\circ} \mathrm{C}\right)$ & Upp. $\left({ }^{\circ} \mathrm{C}\right)$ & HKSAR & Guangdong & HKSAR & Guangdong & $\begin{array}{c}\text { [a] } \\
\text { HKSAR }\end{array}$ & $\begin{array}{c}\text { [b] } \\
\text { Guangdong }\end{array}$ & \\
\hline MV & 24.6 & 13.5 & 7 & 12.5 & 12,103 & 11,664 & 9426 & 8738 & $\begin{array}{l}21,529 \\
\text { (Base) }\end{array}$ & 20,402 & $-5.2 \%$ \\
\hline DV & 25.1 & 15.4 & 10 & 15.5 & 7798 & 7559 & 8697 & 8149 & $\begin{array}{c}16,495 \\
(-23.38 \%)\end{array}$ & $\begin{array}{c}15,707 \\
(-23.01 \%) \\
\end{array}$ & $-4.8 \%$ \\
\hline SV & 27.3 & 17.5 & 12.5 & 17.5 & 4709 & 4678 & 8519 & 8012 & $\begin{array}{c}13,228 \\
(-38.56 \%)\end{array}$ & $\begin{array}{c}12,690 \\
(-37.80 \%)\end{array}$ & $-4.1 \%$ \\
\hline
\end{tabular}

${ }^{* 1}$ The room temperature is based on their neutral temperatures for each ventilation systems. ${ }^{* 2}$ The all-year-round power consumes for chiller, fan and pump.

Table 7. Comparison of $\mathrm{CO}_{2}$ emission, $\mathrm{kg} \mathrm{CO}_{2}$-eq in mixing-, displacement- and stratum ventilation system in supply-and installation and operation phases.

\begin{tabular}{|c|c|c|c|c|c|c|}
\hline \multirow[t]{2}{*}{ Ventilation System } & \multirow{2}{*}{$\begin{array}{l}\text { [a] } \mathrm{CO}_{2} \text { Emission in Supply and Installation } \\
\text { Phase See Table 4, } \mathrm{kg} \mathrm{CO}_{2} \text {-eq }\end{array}$} & \multirow{2}{*}{$\begin{array}{l}\text { [b] } \mathrm{CO}_{2} \text { Emission in Operation Phase See Table 6, } \\
\qquad \mathrm{kg} \mathrm{CO}_{2} \text {-eq }\end{array}$} & \multicolumn{4}{|c|}{$\begin{array}{l}\text { Total } \mathrm{CO}_{2} \text { Emission at the End of Service Years } \\
\qquad[\mathrm{a}]+\mathrm{n} \times[\mathrm{b}] * 1\end{array}$} \\
\hline & & & 5 & 10 & 15 & 20 \\
\hline (1) $\mathrm{MV}_{\mathrm{HK}}$ & 6286 & 11,626 & 64,416 & 122,546 & 180,676 & 238,806 \\
\hline \%diff. with $(2) /(1) * 3$ & {$[15.55 \%]$} & {$[10.55 \%]$} & {$[11.04 \%]$} & {$[10.81 \%]$} & {$[10.73 \%]$} & {$[10.69 \%]$} \\
\hline (3) $\mathrm{DV}_{\mathrm{HK}}$ & 4847 & 8907 & 49,382 & 93,917 & 138,452 & 182,987 \\
\hline $\mathrm{DV} / \mathrm{MV}_{(\mathrm{HK})}{ }^{* 2}$ & $(-33.26 \%)$ & $(-30.70 \%)$ & $(-30.96 \%)$ & $(-30.84 \%)$ & $(-30.79 \%)$ & $(-30.77 \%)$ \\
\hline (4) $\mathrm{DV}_{\mathrm{GD}}$ & 5604 & 9896 & 55,084 & 104,564 & 154,044 & 203,524 \\
\hline $\mathrm{DV} / \mathrm{MV}_{(\mathrm{GD})} * 2$ & $(-22.84 \%)$ & $(-23.01 \%)$ & $(-22.99 \%)$ & $(-23.00 \%)$ & $(-23.00 \%)$ & $(-23.00 \%)$ \\
\hline$\%$ diff. with (4)/(3)*3 & {$[15.62 \%]$} & {$[11.10 \%]$} & {$[11.55 \%]$} & {$[11.34 \%]$} & {$[11.26 \%]$} & {$[11.22 \%]$} \\
\hline (5) $S V_{\mathrm{HK}}$ & 5522 & 7143 & 41,237 & 76,952 & 112,667 & 148,382 \\
\hline $\mathrm{SV} / \mathrm{MV}_{(\mathrm{HK})}$ & $(-23.97 \%)$ & $(-44.43 \%)$ & $(-42.35 \%)$ & $(-43.33 \%)$ & $(-43.68 \%)$ & $(-43.86 \%)$ \\
\hline (6) $\mathrm{SV}_{\mathrm{GD}}$ & 6376 & 7994 & 46,346 & 86,316 & 126,286 & 166,256 \\
\hline $\mathrm{SV} / \mathrm{MV}_{(\mathrm{GD})} * 2$ & $(-12.21 \%)$ & $(-37.80 \%)$ & $(-35.21 \%)$ & $(-36.44 \%)$ & $(-36.88 \%)$ & $(-37.10 \%)$ \\
\hline$\%$ diff. with $(6) /(5) * 3$ & {$[15.46 \%]$} & {$[11.91 \%]$} & {$[12.39 \%]$} & [12.17\%] & {$[+12.09 \%]$} & {$[12.05 \%]$} \\
\hline
\end{tabular}

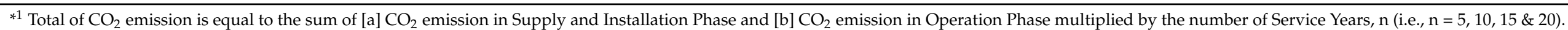

$* 2$ Percentage difference of the $\mathrm{CO}_{2}$ emission of DV and SV comparison with MV in the same region. ${ }^{* 3}$ Percentage difference of the regional $\mathrm{CO}_{2}$ emission of correspondence ventilation installation. 


\subsection{Regional LCC of three Ventilation Systems for 20 Service Years}

The overall regional LCC of the MV, DV, and SV in Guangdong and HKSAR in terms of net present value (NPV) for 5, 10, 15 and 20 years of service are presented in this section. The formula for calculating life-cycle cost is presented as Equation (1):

$$
\mathrm{LCC}(\mathrm{Yr}-\mathrm{n})=\mathrm{IC}_{\mathrm{AHU}}+\mathrm{IC}_{\text {Duct }}+\sum \mathrm{n} \times \mathrm{OC}+\sum \mathrm{n} \times \mathrm{MC}
$$

where,

LCC (Yr-n): Total life-cycle cost in present value for $n$ Service years.

$\mathrm{IC}_{\mathrm{AHU}}$ : Initial cost for the AHU used in this study (See the items 1.1 to 1.7 in Table 1).

$\mathrm{IC}_{\text {Duct }}$ : Initial cost for the ductwork used in this study (See Table 1).

OC: Operating cost for the selected ventilation system annually.

MC: Maintenance cost for the selected ventilation system.

The operating costs for MV, SV, and SV were projected from the year-round energy consumption of the selected ventilation system to maintain indoor human comfort under the air-conditioned zone in Table 6. The electricity tariff of HK\$ 1.132/kWh and RMB¥ $0.6 / \mathrm{kWh}$ (approximately equal to HK\$ $0.71 / \mathrm{kWh}$ ) were adopted for this study in HKSAR and Guangdong respectively. Maintenance cost for the selected ventilation system which assumed to be $6 \%$ of the IC ( $\mathrm{IC}_{\mathrm{AHU}}+\mathrm{IC}_{\text {Duct }}$ ). Equation (2) provide a base of the present value (PV) factor to find out an equivalent present value occurring in " $n$ " years in the future. The estimated PV factors in various Service years in this regional LCC analysis are tabulated in Table 8a.

$$
\operatorname{PV} \text { factor }(\mathrm{n}, \mathrm{k}, \mathrm{i})=\frac{1}{\mathrm{i}-\mathrm{k}}\left(1-{\frac{(1+\mathrm{k})^{\mathrm{n}}}{(1+\mathrm{i})^{\mathrm{n}}}}^{\mathrm{n}}\right),
$$

where

$\mathrm{n}=$ number of service years in 5,10,15 \& 20 .

$\mathrm{I}=$ annual discount rate, $\mathrm{i}_{\mathrm{HK}} \& \mathrm{i}_{\mathrm{GD}}=0.025$ (i.e., $2.5 \%$ ) in HKSAR \& Guangdong

$\mathrm{k}=$ inflation rate, $\mathrm{k}_{\mathrm{HK}}=0.023(2.3 \%)$ in HKSAR, $\mathrm{k}_{\mathrm{GD}}=0.0435(4.35 \%)$ in Guangdong

Table 8. a. Present value factor for LCC analysis. b. Present value (HK\$) of the initial cost of three ventilation system. c. NPV of Operation and Maintenance cost in various Service years. d. Regional

\begin{tabular}{|c|c|c|c|c|}
\hline \multicolumn{5}{|c|}{ a. Present Value (PV) Factor for LCC Analysis in "n" Service Vears } \\
\hline Region & $\mathrm{n}=5$ & $\mathrm{n}=10$ & $\mathrm{n}=15$ & $\mathrm{n}=20$ \\
\hline HKSAR & 4.8590 & 9.6709 & 14.4359 & 19.1547 \\
\hline Guandong & 5.0573 & 10.5879 & 16.6358 & 23.2496 \\
\hline \multicolumn{5}{|c|}{ b. Present Value (HK\$) of the Initial Cost of Three Ventilation System } \\
\hline Region & $\begin{array}{c}\text { Mixing } \\
\text { ventilation } \\
(\mathrm{MV})\end{array}$ & $\begin{array}{l}\text { Displacement } \\
\text { ventilation } \\
\text { (DV) }\end{array}$ & \multicolumn{2}{|c|}{ Stratum ventilation (SV) } \\
\hline HKSAR & 227,980 & 219,370 & \multicolumn{2}{|c|}{226,110} \\
\hline Guandong & 162,480 & 156,642 & \multicolumn{2}{|c|}{159,797} \\
\hline \multicolumn{5}{|c|}{ c. Present Value (PV) of Operation and Maintenance Cost in "n" Service Years } \\
\hline Ventilation System & $\mathrm{n}=5$ & $\mathrm{n}=10$ & $\mathrm{n}=15$ & $\mathrm{n}=20$ \\
\hline$O \& \mathrm{MC}_{\mathrm{MV}(\mathrm{HK})}$ & 173,807 & 345,926 & 516,371 & 685,161 \\
\hline$O \& \mathrm{MC}_{\mathrm{MV}(\mathrm{GD})}$ & 122,561 & 256,590 & 403,158 & 563,439 \\
\hline $\mathrm{O}_{\mathrm{D}} \mathrm{MC}_{\mathrm{DV}(\mathrm{HK})}$ & 144,026 & 286,653 & 427,894 & 567,762 \\
\hline $\mathrm{O} \& \mathrm{MC} C_{\mathrm{DV}(\mathrm{GD})}$ & 103,932 & 217,588 & 341,878 & 477,797 \\
\hline $\mathrm{O}_{\mathrm{SM}} \mathrm{MC}_{\mathrm{SV}(\mathrm{HK})}$ & 127,694 & 254,147 & 379,371 & 503,378 \\
\hline $\mathrm{O}_{\mathrm{SM}} \mathrm{C}_{\mathrm{SV}(\mathrm{GD})}$ & 94,054 & 196,907 & 309,383 & 432,383 \\
\hline
\end{tabular}
LCC of three ventilation systems in term of Net Present Value (HK\$). 
Table 8. Cont.

\begin{tabular}{|c|c|c|c|c|}
\hline \multicolumn{5}{|c|}{ d } \\
\hline \multirow[t]{2}{*}{ Item } & \multicolumn{4}{|c|}{ Net Present Value (NPV) in "n" Service Years } \\
\hline & $\mathrm{n}=5$ & $\mathrm{n}=10$ & $\mathrm{n}=15$ & $\mathrm{n}=20$ \\
\hline \multicolumn{5}{|c|}{ Life Cycle Cost ${ }^{* 1}, \mathrm{HK} \$$ for Mixing Ventilation, as a reference case for comparison } \\
\hline $\mathrm{LCC}_{\mathrm{MV}(\mathrm{HK})}$ & 401,787 & 573,906 & 744,351 & 913,141 \\
\hline $\mathrm{LCC}_{\mathrm{MV}(\mathrm{GD})}$ & 285,041 & 419,070 & 565,638 & 725,919 \\
\hline \multicolumn{5}{|c|}{ Life Cycle Cost ${ }^{* 1}, \mathrm{HK} \$$ for Displacement Ventilation } \\
\hline $\mathrm{LCC}_{\mathrm{DV}(\mathrm{HK})}$ & 363,396 & 506,023 & 647,264 & 787,132 \\
\hline$[\%$ difference of LCC $\mathrm{DV} / \mathrm{MV}(\mathrm{HK})]$ & {$[-9.56 \%]$} & {$[-11.83 \%]$} & {$[-13.04 \%]$} & {$[-13.80 \%]$} \\
\hline $\mathrm{LCC}_{\mathrm{DV}(\mathrm{GD})}$ & 260,574 & 374,230 & 498,520 & 634,439 \\
\hline$\left[\%\right.$ difference of $\left.\mathrm{LCC}_{\mathrm{DV} / \mathrm{MV}(\mathrm{GD})}\right]$ & {$[-8.58 \%]$} & {$[-10.70 \%]$} & {$[-11.87 \%]$} & {$[-12.60 \%]$} \\
\hline \multicolumn{5}{|c|}{ Life Cycle Cost ${ }^{* 1}, \mathrm{HK} \$$ for Stratum Ventilation } \\
\hline $\mathrm{LCC}_{\mathrm{SV}(\mathrm{HK})}$ & 353,804 & 480,257 & 605,481 & 729,488 \\
\hline$\left[\%\right.$ difference of $\left.\mathrm{LCC}_{\mathrm{SV} / \mathrm{MV}(\mathrm{HK})}\right]$ & {$[-11.94 \%]$} & {$[-16.32 \%]$} & {$[-18.66 \%]$} & {$[-20.11 \%]$} \\
\hline $\mathrm{LCC}_{\mathrm{SV}(\mathrm{DG})}$ & 253,850 & 356,704 & 469,180 & 592,180 \\
\hline$\left[\%\right.$ difference of $\left.\mathrm{LCC}_{\mathrm{SV} / \mathrm{MV}(\mathrm{GD})}\right]$ & {$[-10.94 \%]$} & {$[-14.88 \%]$} & {$[-17.05 \%]$} & {$[-18.42 \%]$} \\
\hline
\end{tabular}

Presented in Table $8 \mathbf{b}$, the present value of each initial cost for three ventilation systems is projected from the data as shown in Table 1. By substituting the given information into the above Equations (1) and (2), LCC, net present value (NPV) of three ventilation systems in various service years are tabulated in Table $8 \mathrm{c}$.

LCC of mixing, displacement, stratum ventilation system in HKSAR are $\$ 913,141$ (base), $\$ 787,132(-13.80 \%)$ and $\$ 729,488(-20.11 \%)$ in 20 years of service span respectively, as shown in Table 8d. In Guangdong, LCC of mixing, displacement, stratum ventilation method serving by three systems are $\$ 725,919$ (base), $\$ 634,439$ (12.60\%) and $\$ 592,180$ $(-18.42 \%)$ respectively. It found that the trend of LCC for three ventilation systems is $\mathrm{SV}<\mathrm{DV}<\mathrm{MV}$ in both HKSAR and Guangdong.

Initial Costs for various ventilation systems are tabulated in Table 1. The energy consumption for the different ventilation systems can be acquired in Table 6 to calculate the operating costs for those systems. The regional LCC study focuses on comparing different components of each system of ventilation. At the end of 20 years of operation, the regional LCC in Guangdong for MV, DV \& SV are significantly lower than HKSAR, those are $\$ 913,141 \& \$ 725,919$ for mixing ventilation, $\$ 787,132 \& \$ 634,439$ for displacement ventilation, as well as $\$ 729,488 \& \$ 592,180$ for stratum ventilation. The percentage differences in LCC analysis for MV, DV \& SV in Guangdong are less than $20.5 \%, 19.4 \%$ and $18.82 \%$ in HKSAR. Regional LCC computation for Hong Kong and Guangdong is demonstrated in Table 9. The percentage differences of regional LCC for MV, DV \& SV in Guangdong are less than $20.5 \%, 19.4 \%$ and $18.82 \%$ HKSAR.

Table 9. Regional LCC (HK\$) comparison of three ventilation systems.

\begin{tabular}{|c|c|c|c|c|}
\hline \multirow{2}{*}{ Item } & \multicolumn{4}{|c|}{ Regional LCC Compare with the various Service Years } \\
\hline & 5 & 10 & 15 & 20 \\
\hline \multicolumn{5}{|c|}{ Regional LCC of Mixing Ventilation in HKSAR and Guangdong } \\
\hline $\mathrm{LCC}_{\mathrm{MV}(\mathrm{HK})}$ & $\$ 401,787$ & $\$ 573,906$ & $\$ 744,351$ & $\$ 913,141$ \\
\hline $\mathrm{LCC}_{\mathrm{MV}(\mathrm{GD})}$ & $\$ 285,041$ & $\$ 419,070$ & $\$ 565,638$ & $\$ 725,919$ \\
\hline$\%$ difference of MV in Guangdong & $-29.06 \%$ & $-26.98 \%$ & $-24.01 \%$ & $-20.50 \%$ \\
\hline \multicolumn{5}{|c|}{ Regional LCC of Displacement Ventilation in HKSAR and Guangdong } \\
\hline $\mathrm{LCC}_{\mathrm{DV}(\mathrm{HK})}$ & $\$ 363,396$ & $\$ 506,023$ & $\$ 647,264$ & $\$ 787,132$ \\
\hline $\mathrm{LCC}_{\mathrm{DV}(\mathrm{GD})}$ & $\$ 260,574$ & $\$ 374,230$ & $\$ 498,520$ & $\$ 634,439$ \\
\hline$\%$ difference of DV in Guangdong & $-28.29 \%$ & $-26.04 \%$ & $-22.98 \%$ & $-19.40 \%$ \\
\hline \multicolumn{5}{|c|}{ Regional LCC of Stratum Ventilation in HKSAR and Guangdong } \\
\hline $\mathrm{LCC}_{\mathrm{SV}(\mathrm{HK})}$ & $\$ 353,804$ & $\$ 480,257$ & $\$ 605,481$ & $\$ 729,488$ \\
\hline $\mathrm{LCC}_{\mathrm{SV}(\mathrm{GD})}$ & $\$ 253,850$ & $\$ 356,704$ & $\$ 469,180$ & $\$ 592,180$ \\
\hline$\%$ difference of SV in Guangdong & $-28.25 \%$ & $-25.73 \%$ & $-22.51 \%$ & $-18.82 \%$ \\
\hline
\end{tabular}




\section{Discussion}

The local impact on the process of supply-and-installation and operation phase has been considered in the regional LCA investigation of the equipment and each component for various ventilation strategies, such as supply and installation cost, transportation distance between manufacturer and installed system location. The totals accumulated energy of the MV, DV, and SV strategies in the supply-and-installation phase, as well as operation phase, should be considering all regional factors in the assessment and quantification of the actual impact on the environment of the product's embedded energy in those three ventilation strategies in different regions.

\subsection{The Regional Effect in the Supply-and-Installation Phase}

As presented in Table 1, the initial costs for DV \& SV in Guangdong are less than $3.78 \%$ \& $0.82 \%$ and $3.59 \%$ and $1.65 \%$ in HKSAR respectively that of mixing ventilation. The trend of the initial cost of three ventilation strategies in both regions is the same with SV $<\mathrm{DV}<\mathrm{MV}$. The initial cost savings for DV and SV are less as the amount of the air ductwork used is lesser than MV, because their air ductwork size is smaller than the mixing ventilation system. The initial cost in Guangdong is less than around $29 \%$ of that ventilation systems in HKSAR. SV and DV use less material than that by MV. The percentage differences of regional LCC for MV, DV \& SV in Guangdong are less than 20.5\%, $19.4 \%$ and $18.82 \%$ HKSAR. In addition, the annual energy consumption by SV and DV is less than MV. Thus, the SV's and DV's embedded energy and carbon emission are less than MV.

Due to the system components installed in both studied regions are produced in the area of Guangdong's Pearl River Delta located in Mainland China, their LCI of the embedded carbon in each system component are similar to another region. If the system components are made by other manufacturer location, the correspondence LCI will be significantly dominated by the territorial factor at the level of production. The diversity in embedded energy was supposed in various LCI databases within the correspondence territories. Moreover, the impact on the environment from various ventilation strategies may be significantly affected by the selection of various strategies of construction, material, and size of equipment for the installed air-conditioned medium-sized space. For instance, during the construction process, scaffolding work is a critical approach to install the air ductwork and AHU mounted at a high level. Stratum ventilation is supposed to be further decreased because it is mounted at the occupant level. The ultimate resolution of regional LCA on different ventilation strategies should consist of a negotiated scope for determining regional carbon emissions of building materials from various supply locations at the "cradle to as-built" level of the product.

\subsection{Regional Effect in the Operation Phase}

Considering the 20 years of services span, embedded energy, emissions of carbon dioxide, neutral temperature, all-year energy consumption, and regional LCC or MV, DV \& SV, utilizing regional LCA methodological analysis, it is found that the SV in Hong Kong and Guangdong has the least energy consumption with $38.56 \%$ \& $37.80 \%$ less than that of $M V, M V_{(H K)} \& M_{(G D)}$. The detail is shown in Table 6.

The LCI data is territory-specified because the mixtures of the fuels and the method of production frequently vary from region to region. Operation costs $\left(\mathrm{OC}_{\mathrm{MC}}, \mathrm{OC}_{\mathrm{DV}} \&\right.$ $\mathrm{OC}_{\mathrm{SV}}$ ) are established on the electricity tariff of $\mathrm{HK} \$ 1.132 / \mathrm{kWh}$ (Hong Kong) and RMB¥ $0.6 / \mathrm{kWh}$ (Guangdong) times the year-round energy consumption as presented in Table 8 . The maintenance cost for the selected ventilation system is assumed to be $6 \%$ of the IC $\left(\mathrm{IC}_{\mathrm{AHU}}+\mathrm{IC}_{\text {Duct }}\right)$.

In term of $\mathrm{CO}_{2}$ emission consideration, emission factors of $\mathrm{CO}_{2}$ in HKSAR and Guangdong are 0.54 and $0.63 \mathrm{kgCO}_{2}$-eq $/ \mathrm{kWh}$ respectively to be applied. The trends of emission of carbon for the MV, DV \& SV throughout the supply-and-install phase \& 
operation phase is SV $<\mathrm{DV}<\mathrm{MV}$. This results in line with the latter-day year-round energy performance studies concerning various ventilation strategies for cooling [61,62].

The author expects that Renewable energy is being set up faster than ever. According to the Renewable Energy Policy Network for the 21st Century [63], the largest annual increase in global renewable generation capacity ever, with new solar photovoltaic capacity outstripping additions in coal, natural gas and nuclear power combined. This is one of several hopeful signs that the "cleantech" sector is rising to the challenge of climate change. Therefore, the different carbon emission factor for estimating the actual amount of carbon emission will be affected by a different combination of coal, natural gas, nuclear power and renewable energy generation combined for the correspondence country. Carbon emissions embedded in the supply process of a built facility or cradle-to-gate is a significant problem but often overlooked. The framework of assessment work for providing a specific requirement in line with the different imported ventilation strategies' production processes and those formulated in the current locale as well as international best practices.

\subsection{Regional LCA and LCC}

It is found that stratum ventilation has the least $\mathrm{CO}_{2}$ emission with $43.86 \% \& 37.10 \%$ less than that of $\mathrm{MV}_{(\mathrm{HK})} \& \mathrm{MV}_{(\mathrm{GD})}$ in Table 7, and the least regional LCC with $20.11 \%$ \& $18.42 \%$ lower than that of $\mathrm{MV}_{(\mathrm{HK})} \& \mathrm{MV}_{(\mathrm{GD})}$ in Table $8 \mathrm{~d}$ during 20 Service years. $\mathrm{LCC}$ in Guangdong is significantly cheaper than HKSAR, those percentage differences for MV, DV $\&$ SV are $-20.50 \%,-19.40 \%$ and $-18.82 \%$ respectively.

The regional LCC \& LCA model has considered the technical performance of regional conditions incorporating transportation distance from a manufacturer, weather design data, energy simulation result, carbon emission factor, as well as the thermal comfort expectation in the various ventilation system. In comparing with HKSAR, the percentage difference of $\mathrm{CO}_{2}$ emission of MV, DV and SV in Guangdong is $+10.69 \%,+11.22 \%$ and $+12.05 \%, \%$ respectively in 20 years of service span (see Figure 3).

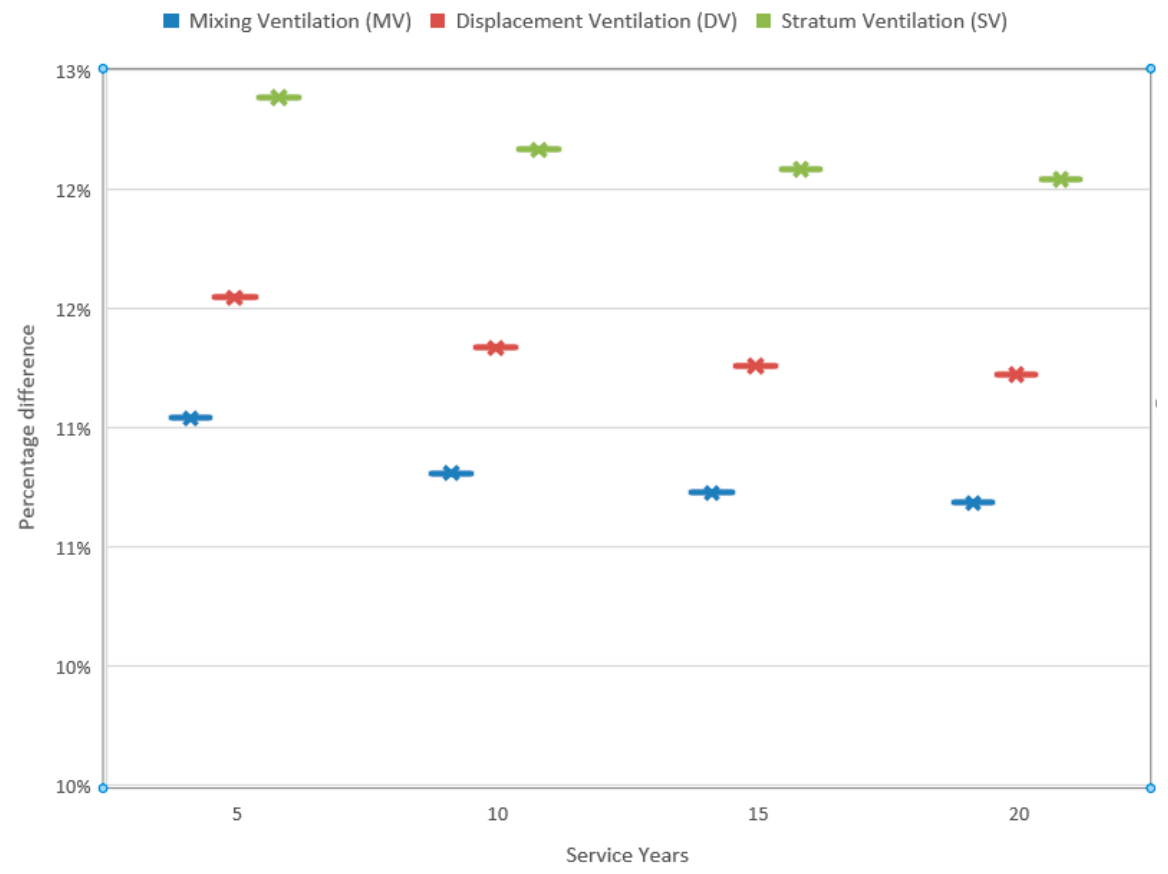

Figure 3. Percentage difference of regional $\mathrm{CO}_{2}$ emission in mixing-, displacement- and stratumventilated medium-sized space in between HKSAR and Guangdong.

\section{Conclusions}

The trend of the three ventilation strategies serving the medium-sized space in both cases located at HKSAR and Guangdong are found that their regional LCA and LCC results are the same, those are $\mathrm{SV}_{\mathrm{HK}}<\mathrm{DV}_{\mathrm{HK}}<\mathrm{MV}_{\mathrm{HK}}$ and $\mathrm{SV}_{\mathrm{GD}}<\mathrm{DV} V_{\mathrm{GD}}<\mathrm{MV} V_{\mathrm{GD}}$ respectively. In 
three ventilation systems, stratum ventilation is the best option, based on their respective neutral temperature of ventilation systems and their weather condition, to alleviate the regional cost data and emission of $\mathrm{CO}_{2}$ in HKSAR and Guangdong. These results have considered the $\mathrm{CO}_{2}$ emission in both the supply-and-installation phase as well as operation phase of three ventilation system. Regional LCC analysis in Guangdong is cheaper than that of HKSAR. The percentage differences of regional LCC for MV, DV \& SV in Guangdong are less than $20.5 \%, 19.4 \%$ and $18.82 \%$ in HKSAR. In comparing with HKSAR, the percentage differences of $\mathrm{CO}_{2}$ emission of MV, DV and SV in Guangdong are $+10.69 \%,+11.22 \%$ and $+12.05 \%$ respectively in the 20 years of service span.

Overlooking the embedded energy as well as the regional LCA \& LCC effect in the supply-and-installation phase can be prevented in this analysis model. The results are based on various values of enthalpy of three ventilation systems, their regional carbon emission factor, weather condition of the room air in the operation phase in HKSAR and Guangdong. It is a better way to evaluate the local and entire significance of their environment prior to the selection of a ventilation strategy in a different region. This regional LCC \& LCA model is helpful for the development of high efficiency and cost-effective ventilation strategy for industries with different local factors.

Funding: Not applicable.

Institutional Review Board Statement: Not applicable.

Informed Consent Statement: Not applicable.

Data Availability Statement: Not applicable.

Acknowledgments: The author would like to express our gratitude to Division of Building Science \& Technology, City University of Hong Kong who supported and provided the data on this study of various ventilation strategies inside the test chamber. The author thanks Tsang Kai Kwong for English and Mathematics editing.

Conflicts of Interest: Authors declare no conflict of interest.

\section{Nomenclature}

\begin{tabular}{|c|c|}
\hline AHU & Air handling Unit \\
\hline $\mathrm{CO}_{2}$ & Carbon dioxide \\
\hline DDC & Direct digital controller \\
\hline DV & Displacement ventilation \\
\hline $\mathrm{DV}_{(\mathrm{HK})}$ & Displacement ventilation method in HKSAR \\
\hline $\mathrm{DV} / \mathrm{MV}_{(\mathrm{HK})}$ & Percentage difference between DV in comparing with MV in HKSAR \\
\hline $\mathrm{DV}_{(\mathrm{GD})}$ & Displacement ventilation method in Guangdong \\
\hline $\mathrm{DV} / \mathrm{MV}_{(\mathrm{GD})}$ & Percentage difference between DV in comparing with MV in Guangdong \\
\hline ELCD & European Life Cycle Database \\
\hline EMSD & Electrical and Mechanical Services Department \\
\hline HKEPD & HKSAR Environmental Protection Department \\
\hline HK\$ & Hong Kong dollar \\
\hline HKSAR & Hong Kong Special Administration Region \\
\hline HVAC & Heating, ventilation and air conditioning \\
\hline i & Annual discount rate $(\%)$ \\
\hline IC & Initial cost $(\mathrm{HK} \$)$ \\
\hline ICE & Inventory of carbon \& energy \\
\hline k & Inflation rate $(\%)$ \\
\hline LCA & Life cycle assessment \\
\hline LCC & Life cycle cost \\
\hline $\mathrm{LCC}_{\mathrm{DV}(\mathrm{HK})}$ & Life cycle cost of displacement ventilation method in HKSAR \\
\hline $\mathrm{LCC}_{\mathrm{DV}(\mathrm{GD})}$ & Life cycle cost of displacement ventilation method in Guangdong \\
\hline $\mathrm{LCC}_{\mathrm{DV} / \mathrm{MV}(\mathrm{HK})}$ & $\begin{array}{l}\text { Percentage difference between } \mathrm{LCCDV}(\mathrm{HK}) \text { in comparing with } \mathrm{LCCMV}(\mathrm{HK}) \\
\text { in HKSAR }\end{array}$ \\
\hline
\end{tabular}




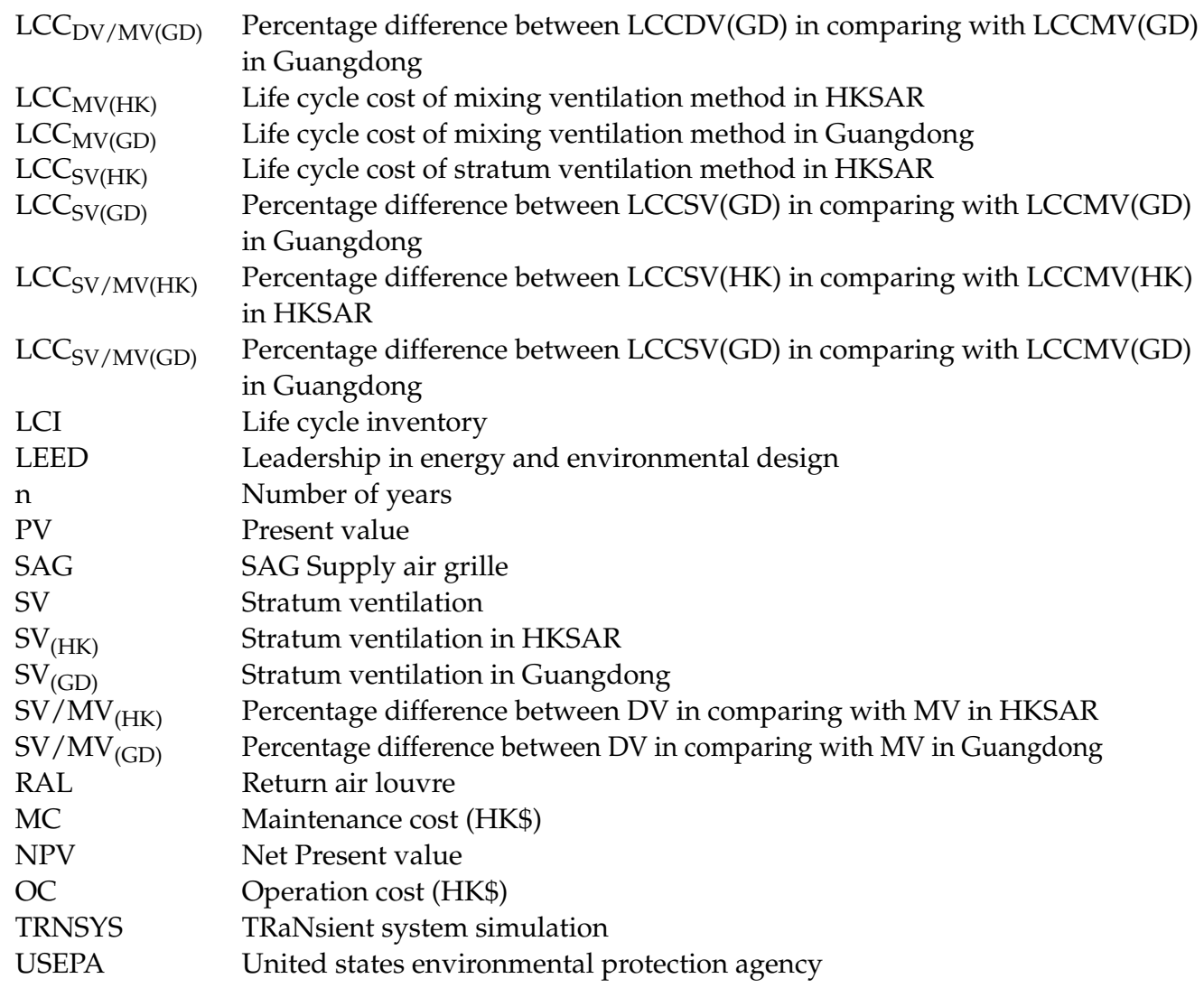

\section{References}

1. Cubi, E.; Doluweera, G.; Bergerson, J. Incorporation of electricity GHG emissions intensity variability into building environmental assessment. Appl. Energy 2015, 159, 62-69. [CrossRef]

2. Xiao, H.; Wei, Q.; Jiang, Y. The reality and statistical distribution of energy consumption in office buildings in China. Energy Build. 2012, 50, 259-265. [CrossRef]

3. IPCC Summary for Policymakers of IPCC Special Report on Global Warming of $1.5^{\circ} \mathrm{C}$ Approved by Governments. Available online: https:/ / www.ipcc.ch/2018/10/08/summary-for-policymakers-of-ipcc-special-report-on-global-warming-of-15c-approved-by-governments/ (accessed on 3 February 2020).

4. Outline of the 14th Five-Year Plan. For National Economic and Social Development of the People's Republic of China; The government of the People's Republic of China: Beijing, China, 2021.

5. Dong, F.; Bian, Z.; Yu, B.; Wang, Y.; Zhang, S.; Li, J.; Su, B.; Long, R. Can land urbanization help to achieve $\mathrm{CO}_{2}$ intensity reduction target or hinder it? Evidence from China. Resour. Conserv. Recycl. 2018, 134, 206-215. [CrossRef]

6. Wu, C.B.; Huang, G.H.; Xin, B.G.; Chen, J.K. Scenario analysis of carbon emissions' anti-driving effect on Qingdao's energy structure adjustment with an optimization model, Part I: Carbon emissions peak value prediction. J. Clean. Prod. 2018, 172, 466-474. [CrossRef]

7. Anand, C.K.; Amor, B. Recent developments, future challenges and new research directions in LCA of buildings: A critical review. Renew. Sustain. Energy Rev. 2017, 67, 408-416. [CrossRef]

8. Dong, F.; Hua, Y.; Yu, B. Peak carbon emissions in China: Status, key factors and countermeasures-A literature review. Sustainability 2018, 10, 2895. [CrossRef]

9. Dong, F.; Wang, Y.; Su, B.; Hua, Y.; Zhang, Y. The process of peak $\mathrm{CO}_{2}$ emissions in developed economies: A perspective of industrialization and urbanization. Resour. Conserv. Recycl. 2019, 141, 61-75. [CrossRef]

10. Energy Saving Policy Plan for Hong Kong's Built Environment 2015-2025+; Environment Bureau of HKSAR: Hong Kong, China, 2015.

11. Kapsalaki, M.; Leal, V.; Santamouris, M. A methodology for economic efficient design of Net Zero Energy Buildings. Energy Build. 2012, 55, 765-778. [CrossRef]

12. HKEMSD Hong Kong Energy End-use Data 2020. Available online: http://www.emsd.gov.hk/emsd/e_download/pee/ HKEEUD2020.pdf (accessed on 1 April 2021).

13. ISO. ISO 14040: Environmental management-Life Cycle Assessment-Principles and Framework; Int. Organ. Stand.: Geneva, Switzerland, 2006.

14. Heinonen, J.; Säynäjoki, A.; Junnonen, J.M.; Pöyry, A.; Junnila, S. Pre-use phase LCA of a multi-story residential building: Can greenhouse gas emissions be used as a more general environmental performance indicator? Build. Environ. 2016, 95, 116-125. [CrossRef] 
15. Kajikawa, Y.; Inoue, T.; Goh, T.N. Analysis of building environment assessment frameworks and their implications for sustainability indicators. Sustain. Sci. 2011, 6, 233-246. [CrossRef]

16. Leadership in Energy and Environmental Design (LEED). Available online: https://www.usgbc.org/leed (accessed on 3 February 2020).

17. Building Research Establishment Environmental Assessment Method (BREEAM). Available online: https://www.breeam.com/ (accessed on 3 February 2020).

18. Green Star in Australia. Available online: https://new.gbca.org.au/green-star/ (accessed on 3 February 2020).

19. Life Cycle Assessment (LCA) and Life Cycle Cost (LCC) Tool for Commercial Building Developments in Hong Kong; Electrical and Mechanical Services Department of HKSAR: Hong Kong, China, 2006.

20. Green Mark in Singapore. Available online: https://www.bca.gov.sg/greenmark/green_mark_buildings.html (accessed on 4 February 2020).

21. Cole, R.J.; Valdebenito, M.J. The importation of building environmental certification systems: International usages of BREEAM and LEED. Build. Res. Inf. 2013, 41, 662-676. [CrossRef]

22. Schweber, L. The effect of BREEAM on clients and construction professionals. Build. Res. Inf. 2013, 41, 129-145. [CrossRef]

23. Hernandez, P.; Kenny, P. Development of a methodology for life cycle building energy ratings. Energy Policy 2011, 39, 3779-3788. [CrossRef]

24. Consultancy Study on Life Cycle Energy Analysis of Building Construction-An. Introduction to Life Cycle energy Assessment (LCEA) of Building Deelopments, a Report Submitted by Ove Arup and Partners; Consultancy Agreement No. CAO L013; Electrical and Mechanical Services Department of HKSAR: Hong Kong, China, 2006.

25. Fong, A.M.-L. A Study of Thermal Comfort and Cost Effectiveness of Stratum Ventilation; De Montfort University: Leicester, UK, 2014.

26. Fong, M.L.; Lin, Z.; Fong, K.F.; Hanby, V.; Greenough, R. Life cycle assessment for three ventilation methods. Build. Environ. 2017, 116, 73-88. [CrossRef]

27. Ecoinvent-Life Cycle Inventory Database. Available online: https:/ /www.ecoinvent.org/database/database.html (accessed on 3 February 2020).

28. European Reference Life Cycle Database (ELCD). Available online: https:/ / eplca.jrc.ec.europa.eu/index.html\#menu1 (accessed on 3 February 2020).

29. eBalance User Manunal (Chinese Version 3.0); Integrated Knowledge for our Environment: Beijing, China, 2012.

30. Ibn-Mohammed, T.; Greenough, R.; Taylor, S.; Ozawa-Meida, L.; Acquaye, A. Integrating economic considerations with operational and embodied emissions into a decision support system for the optimal ranking of building retrofit options. Build. Environ. 2014, 72, 82-101. [CrossRef]

31. Han, G.; Srebric, J.; Enache-Pommer, E. Variability of optimal solutions for building components based on comprehensive life cycle cost analysis. Energy Build. 2014, 79, 223-231. [CrossRef]

32. Gustavsson, L.; Joelsson, A. Life cycle primary energy analysis of residential buildings. Energy Build. 2010, 42, 210-220. [CrossRef]

33. Bevington, R.; Rosenfeld, A.H. Energy for buildings and homes. Sci. Am. 1990, 263, 76-87. [CrossRef]

34. Yuan, Y.; Jin, Z. Life cycle assessment of building energy in big-data era: Theory and framework. In Proceedings of the 2015 International Conference on Network and Information Systems for Computers, Wuhan, China, 23-25 January 2015.

35. Lindberg, K.B.; Doorman, G.; Fischer, D.; Korpås, M.; Ånestad, A.; Sartori, I. Methodology for optimal energy system design of Zero Energy Buildings using mixed-integer linear programming. Energy Build. 2016, 127, 194-205. [CrossRef]

36. Fong, M.L.; Lin, Z.; Fong, K.F.; Chow, T.T.; Yao, T. Evaluation of thermal comfort conditions in a classroom with three ventilation methods. Indoor Air 2011, 21, 231-239. [CrossRef]

37. Gangolells, M.; Casals, M.; Gassó, S.; Forcada, N.; Roca, X.; Fuertes, A. A methodology for predicting the severity of environmental impacts related to the construction process of residential buildings. Build. Environ. 2009, 44, 558-571. [CrossRef]

38. Sodagar, B.; Fieldson, R. Towards a sustainable construction practice. Constr. Inf. Q. 2007, 18, 76-82.

39. Erlandsson, M.; Borg, M. Generic LCA-methodology applicable for buildings, constructions and operation services-today practice and development needs. Build. Environ. 2003, 38, 919-938. [CrossRef]

40. United States Environmental Protection Agency. Available online: https://www.epa.gov/aboutepa (accessed on 4 February 2020).

41. Lin, Z.; Chow, T.T.; Tsang, C.F.; Fong, K.F.; Chan, L.S. Stratum ventilation-A potential solution to elevated indoor temperatures. Build. Environ. 2009, 44, 2256-2269. [CrossRef]

42. Wang, X.; Lin, Z. An experimental investigation into the pull-down performances with different air distributions. Appl. Therm. Eng. 2015, 91, 151-162. [CrossRef]

43. Cheng, Y.; Lin, Z. Experimental study of airflow characteristics of stratum ventilation in a multi-occupant room with comparison to mixing ventilation and displacement ventilation. Indoor Air 2015, 25, 662-671. [CrossRef]

44. Chai, J.; Huang, P.; Sun, Y. Differential evolution-based system design optimization for net zero energy buildings under climate change. Sustain. Cities Soc. 2020, 55, 102037. [CrossRef]

45. Sharma, A.; Saxena, A.; Sethi, M.; Shree, V. Varun Life cycle assessment of buildings: A review. Renew. Sustain. Energy Rev. 2011, 15, 871-875. [CrossRef]

46. Sartori, I.; Hestnes, A.G. Energy use in the life cycle of conventional and low-energy buildings: A review article. Energy Build. 2007, 39, 249-257. [CrossRef] 
47. Wegener Sleeswijk, A. Regional LCA in a global perspective. A basis for spatially differentiated environmental life cycle assessment. Int. J. Life Cycle Assess. 2011, 16, 106-112. [CrossRef]

48. Tabatabaie, S.M.H.; Bolte, J.P.; Murthy, G.S. A regional scale modeling framework combining biogeochemical model with life cycle and economic analysis for integrated assessment of cropping systems. Sci. Total Environ. 2018, 625, 428-439. [CrossRef] [PubMed]

49. Klein, S.A. TRNSYS 17: A Transient System Simulation Program; Solar Energy Laboratory University: Wisconsin, MA, USA, 2010.

50. Project Cost in Guangdong. Available online: https://gd.zjtcn.com/ (accessed on 4 February 2020).

51. Planning and Management Office of Pearl River Delta urban agglomeration Comprehensive quota of installation works in Guangdong Province 2010. Available online: http:/ / de.yusuan.com/page_content.asp?content=397 (accessed on 1 October 2020).

52. Hong Kong Environmental Protection Department (HKEPD). Available online: https://www.epd.gov.hk/epd/mobile/english/ environmentinhk/waste/waste_maincontent.html (accessed on 4 February 2020).

53. Practice Note for Authorized Persons, Registered Structural Engineers and Registered Geotechnical Engineers ADV-19; Building Department of HKSAR: Hong Kong, China, 2021.

54. Athena Regional LCA Software Tools. Available online: http://www.athenasmi.org/our-software-data/lca-databases/ (accessed on 4 February 2020).

55. The BEES (Building for Environmental and Economic Sustainability) Software. Available online: https://www.nist.gov/servicesresources/software/bees (accessed on 4 February 2020).

56. Envest 2 Environmental Impact Assessment \& Whole Life. Available online: https://www.bregroup.com/products/tools/ impact-lca/ (accessed on 4 February 2020).

57. Fong, M.L.; Hanby, V.; Greenough, R.; Lin, Z.; Cheng, Y. Acceptance of thermal conditions and energy use of three ventilation strategies with six exhaust configurations for the classroom. Build. Environ. 2015, 94, 606-619. [CrossRef]

58. Fanger, P.O. Thermal Comfort: Analysis and Application in Environmental Engineering; McGraw Hill: New York, NY, USA, 1972.

59. ISO. ISO 7730: Ergonomics of the Thermal Environment Analytical Determination and Interpretation of Thermal Comfort Using Calculation of the PMV and PPD Indices and Local Thermal Comfort Criteria; ISO: Geneva, Switzerland, 2005.

60. The American Society of Heat, Refrigerating and Air-Conditioning Engineers. Thermal Environmental Conditions for Human Occupancy; ASHRAE Stand.: Atlanta, GA, USA, 2013.

61. Lee, C.K.; Fong, K.F.; Lin, Z.; Chow, T.T. Year-round energy saving potential of stratum ventilated classrooms with temperature and humidity control. HVACR Res. 2013, 19, 986-991. [CrossRef]

62. Lin, Z.; Lee, C.K.; Fong, S.; Chow, T.T.; Yao, T.; Chan, A.L.S. Comparison of annual energy performances with different ventilation methods for cooling. Energy Build. 2011, 43, 130-136. [CrossRef]

63. Hales, D. Renewables 2018 Global Status Report. Available online: https://opus.cloud.lib.uts.edu.au/bitstream/10453/142688/2 /GSR2018_Full-Report_English.pdf (accessed on 1 April 2021). 